\title{
Assessment of the nematicidal potential of vermicompost, vermicompost tea, and urea application on the potato-cyst nematodes Globodera rostochiensis and Globodera pallida
}

\author{
Marek Renčo ${ }^{1 *}$, Peter Kováčik
}

\author{
${ }^{1}$ Institute of Parasitology, Slovak Academy of Sciences, Hlinkova 3, 040 01, Košice, Slovak Republic \\ ${ }^{2}$ Department of Agrochemistry and Plant Nutrition, Slovak University of Agriculture in Nitra, \\ Tr. A. Hlinku 2, 94901 Nitra, Slovak Republic
}

Received: November 18, 2014

Accepted: May 4, 2015

\begin{abstract}
The addition of organic material to the soil can be an effective alternative to the environmentally unsafe chemical treatments that are used to control plant parasitic nematodes. We evaluated the effects of vermicompost alone, and aqueous solutions of vermicompost (vermicompost tea) either alone or mixed with urea, on the development and survival of two potato-cyst nematodes: Globodera rostochiensis (pathotype Ro1) and G. pallida (pathotype Pa2) and on the growth parameters of the host potato plants. Soil amendments with these materials significantly decreased the number of cysts $\cdot 400 \mathrm{~g}^{-1}$ of both species in the soil, the number of eggs and juveniles $\cdot$ cyst $^{-1}$ of both species, and the number of eggs and juveniles $\cdot \mathrm{g}^{-1}$ of both species in the soil, relative to the untreated controls. The suppressive effect was significantly higher at the highest dose than the lowest treatment dose, for all tested materials. Globodera rostochiensis was more sensitive to all the tested materials than G. pallida. The aqueous solutions of vermicompost alone or in combination with urea were more effective than the solid vermicompost used alone, for controlling both species. Vermicompost and the vermicompost teas had positive effects on plant fresh stem weight and stem height. The application of vermicompost tea instead of the solid vermicompost, substantially decreased the amount of material needed. These amendments are thus promising for the control of potato-cyst nematodes in sustainable agricultural systems.
\end{abstract}

Key words: Eisenia fetida, control, potato cyst nematode, urea, vermicompost, vermicompost tea

\section{Introduction}

The potato-cyst nematodes, Globodera rostochiensis and G. pallida, are economically important plant pathogens. The European and Mediterranean Plant Protection Organisation recommends that they be regulated as quarantine pests (EPPO 2014). These two species can reduce potato yields by $20-70 \%$ (Greco 1988), lower the quality and marketable condition of the tubers, and facilitate infections by other diseases (Vasyukova et al. 2006). An estimated $2 \mathrm{t} \cdot \mathrm{ha}^{-1}$ of potatoes are lost for every 20 eggs and juveniles per gram of soil (Brown 1969). The loss of yield, however, varies depending on nematode species, genotype (pathotype), and population density at sowing, and also on the potato cultivar, climatic conditions, soil type (Evans and Haydock 1990; Oijen et al. 1995), and management (the control) methods were used (Sharma 1998).

The management of plant parasitic nematodes is more difficult than for other pests because plant parasitic nematodes mostly inhabit the soil and usually attack the underground parts of plants (Akhtar 1997). Moreover, the management of cyst nematodes faces a unique problem; gravid females form cysts with hardened protective walls Prevention (avoiding the spread to non-infested regions) is the best and most economical control method, because once a plant is parasitised, the worms cannot be killed without also destroying the host. Chemical nematicides are very effective in controlling plant parasitic nematodes in the soil (Adegbite et al. 2008; Karajeh 2008; Haydock et al. 2013). Chemical treatment is frequently used but is generally considered dangerous to the environment, soil organisms as well as human and animal health. Recent European legislation (CE 396/2005, 1095/2007, 33 and $299 / 2008$, and 1107/2009) has severely restricted and revised the use of pesticides on agricultural crops.

Alternatives with lower environmental impacts and a wider range of options have received much attention. The alternatives must be as effective as synthetic nematicides, readily available, affordable, and safer for farmers, consumers, and the environment. Biofumigation (Avato et al. 2013), mycorrhisation (Sasanelli et al. 2009), plant extracts, essential oils or secondary plant metabolites (Renčo et al. 2014), and organic-waste amendments (Renčo et al. 2011; Renčo 2013) have been successfully used to control plant parasitic nematodes.

Many of the organic wastes produced on farms and by modern industrial technology cause odour problems 
or can pollute groundwater (Edwards et al. 2011). These problems could be attenuated by the biological stabilisation of the wastes. Composting and vermicomposting are two of the best-known methods for the biological stabilisation of solid organic waste. Composting is the accelerated degradation of organic matter by microorganisms under controlled conditions. Under these conditions the organic material undergoes a characteristic thermophilic stage at $45-65^{\circ} \mathrm{C}$ that sanitises the waste by eliminating pathogenic microorganisms (Edwards et al. 2011). The use of earthworms, particularly Eisenia fetida, however, can accelerate the aerobic decomposition of the wastes, thereby minimising odours and pollution (Edwards et al. 2011). This process is faster than composting because the material passes through the earthworm's gut, where a significant but not fully understood transformation occurs. Nevertheless, earthworm droppings (worm manure) are rich in microbial activity and plant-growth regulators and can repel pests (Edwards et al. 2011). The droppings can also be liquefied by the addition of water (vermicompost tea). Unlike solid vermicompost, teas have unique features. Teas can be applied directly to plant foliage or to the soil before and during plant growth and are effective in relatively small quantities (Edwards et al. 2011). Adding various types of solid vermicomposts to soil can decrease arthropod (Arancon et al. 2005) and nematode (Renčo et al. 2011) pests, but aqueous extracts (teas) have previously been tested more as suppressants of plant diseases (Vibha 2010; Edwards et al. 2011).

The present study analysed the suppressive effects of various doses of vermicomposts produced from municipal wastes, and of vermicompost teas, either alone or combined with urea, on the soil populations of two species of potato-cyst nematodes: G. rostochiensis and G. pallida. We hypothesised that the aqueous extracts of solid vermicompost could provide faster and better nematode suppression due to the presence of nutrients, other beneficial substances, and microorganisms in liquid form. We also hypothesised that these vermicompost teas could produce this effect at lower quantities compared to solid vermicompost.

\section{Materials and Methods}

Solid vermicompost derived from municipal green wastes (30\% leaves, $70 \%$ grass) and vermicompost teas derived from the same vermicompost with added water $(1: 5,20 \%)$ were applied to the soil at various doses and times. The vermicompost was mixed with sterilised $\left(80^{\circ} \mathrm{C}\right.$ for $\left.1 \mathrm{~h}\right)$ sandy soil to produce doses of $10,20,40$, and $60 \mathrm{t} \cdot \mathrm{ha}^{-1}$. Each mixture was then added to four 41 clay pots that were each sown with one potato tuber (cv. Désirée). Vermicompost tea alone or in combination with urea (285 g urea $\cdot 1 \mathrm{l}^{-1}$ tea) was applied to the same sterilised soil in similar pots, at rates of 10, 20, 40, and $60 \mathrm{l} \cdot \mathrm{ha}^{-1}$ at potato sowing (single application) and at potato sowing and again one month later (double application). There were four replicates of each treatment. Potato plants grown in sterilised but untreated soil were used as the controls.
One hundred viable cysts of G. rostochiensis [200 eggs and second-stage juveniles (J2s) per cyst] or G. pallida (180 eggs and J2s per cyst) were added to each pot, including the control pots, at the time of sowing. The cysts were enclosed in $2 \times 2 \mathrm{~cm}$ polyester bags. The mesh size of the bags was 300 microns.

The pots were arranged on benches in a randomised block design in a glasshouse at $23 \pm 2^{\circ} \mathrm{C}$. The experiment began on 5 April 2014 and continued for five months. The potato plants were grown until new tubers were formed. At the end of the experiment, the soil from each pot was mixed thoroughly, and a sample (400 g) was collected and air dried. Cysts were extracted by a flotation method (Sabová and Valocká 1980). The extracted cysts were then crushed, and the viable eggs and $\mathrm{J} 2$ number were counted. Data from the experiment were subjected to an analysis of variance (ANOVA), and means were compared by a least significant difference test. The statistical analyses were performed using PlotIT.

\section{Results and Discussion}

Various doses of vermicompost of municipal waste, and aqueous vermicompost tea alone or mixed with urea were applied to the soil. The potential nematicidal effects of these vermicompost and vermicompost tea applications on the reproduction of nematodes were compared and analysed. All the tested materials significantly decreased $(p \leq 0.05)$ the populations of both species relative to the untreated controls. The solid vermicompost, however, was not as effective as its aqueous extract with or without urea. Nevertheless, all tested doses of the solid vermicompost significantly decreased nematode populations relative to the untreated controls (Table 1).

The number of cysts $\cdot 400 \mathrm{~g}^{-1}$ of soil, the number of eggs and $\mathrm{J} 2 \mathrm{~s} \cdot \mathrm{g}^{-1}$ of soil, and thus the reproduction, decreased linearly and inversely with the dose rate of solid vermicompost (Table 1). The suppressive effect was significantly larger $(p \leq 0.05)$ for the highest dose than for the lowest dose. The amended soils also contained significantly fewer eggs and J2s per cyst of both species relative to the controls, confirming the reduced reproduction in the compost-treated soils. Globodera rostochiensis was more sensitive than G. pallida to soil treatments with solid vermicompost. The numbers of cysts $400 \mathrm{~g}^{-1}$ of soil, the numbers of eggs and $\mathrm{J} 2 \mathrm{~s} \cdot \mathrm{g}^{-1}$ of soil, and the reproduction ratio, $r$, were lower at all tested rates (Table 1). These results were consistent with the findings by Arancon et al. (2002), Pandey (2009), Seenivasan and Poornima (2010), and Renčo et al. (2011), where vermicomposts produced from municipal wastes, medicinal plant wastes, cattle manure, food, and paper-recycling wastes significantly reduced the populations of Meloidogyne incognita, G. rostochiensis, G. pallida, and other plant parasitic nematodes.

The application of vermicompost has also been reported to significantly suppress several arthropod pests, such as striped cucumber beetles (Acalymma vittatum), spotted cucumber beetles (Diabrotica undecimpunctata), tobacco hornworms (Manduca quinquemaculata) (Yardim et al. 2006), white caterpillars (Pieris brassicae) (Arancon et al. 2005), spider mites (Tetranychus urticae), mealy bugs 
Table 1. The effect of vermicompost applied at various doses on the mean numbers (four replicates) of Globodera rostochiensis (Ro1) and Globodera pallida (Pa2) eggs and juveniles

\begin{tabular}{|c|c|c|c|c|c|}
\hline \multirow[b]{2}{*}{ Species } & \multirow{2}{*}{$\begin{array}{c}\text { Application } \\
\text { rate } \\
{\left[\mathrm{t} \cdot \mathrm{ha}^{-1}\right]}\end{array}$} & \multicolumn{4}{|c|}{ Number } \\
\hline & & $\begin{array}{l}\text { cysts } \cdot 400 \mathrm{~g}^{-1} \\
\text { of soil }\end{array}$ & $\begin{array}{c}\text { eggs and } \\
\text { juveniles } \cdot \text { cyst }^{-1}\end{array}$ & $\begin{array}{c}\text { eggs and } \\
\text { juveniles } \cdot \mathrm{g}^{-1} \text { of soil }\end{array}$ & $r=P f / P i$ \\
\hline \multirow{5}{*}{$\begin{array}{l}\text { Globodera } \\
\text { rostochiensis }\end{array}$} & 0 & $217.8 \mathrm{a}^{*}$ & $215.3 \mathrm{a}$ & $117.2 \mathrm{a}$ & $23.4 \mathrm{a}$ \\
\hline & 10 & $180.0 \mathrm{~b}$ & $173.8 \mathrm{~b}$ & $78.3 \mathrm{~b}$ & $15.6 \mathrm{~b}$ \\
\hline & 20 & $143.8 \mathrm{c}$ & $166.8 \mathrm{~b}$ & $59.9 c$ & $12.0 \mathrm{c}$ \\
\hline & 40 & $118.3 \mathrm{c}$ & $166.3 \mathrm{~b}$ & $49.2 \mathrm{c}$ & $9.8 \mathrm{~d}$ \\
\hline & 60 & $77.0 \mathrm{~d}$ & $126.3 \mathrm{c}$ & $24.3 \mathrm{~d}$ & $4.9 \mathrm{e}$ \\
\hline \multirow{5}{*}{$\begin{array}{l}\text { Globodera } \\
\text { pallida }\end{array}$} & 0 & $244.5 \mathrm{a}$ & $222.3 \mathrm{a}$ & 135.9 a & $30.2 \mathrm{a}$ \\
\hline & 10 & $192.0 \mathrm{~b}$ & $218.3 \mathrm{a}$ & $104.8 \mathrm{~b}$ & $23.3 b$ \\
\hline & 20 & $169.0 \mathrm{bc}$ & $219.5 \mathrm{a}$ & $92.7 \mathrm{bc}$ & $20.6 b$ \\
\hline & 40 & $159.5 \mathrm{~cd}$ & $184.5 \mathrm{~b}$ & $73.6 \mathrm{~cd}$ & $16.3 \mathrm{c}$ \\
\hline & 60 & $141.3 \mathrm{~d}$ & $177.0 \mathrm{~b}$ & $62.5 \mathrm{~d}$ & $13.9 \mathrm{~d}$ \\
\hline
\end{tabular}

*different letters within a column and species indicate significant differences $(\mathrm{p} \leq 0.05)$

$P f$ - final population density, $P i$ - initial population density

Table 2. The effect of vermicompost tea applied at various doses and times on the mean numbers (four replicates) of Globodera rostochiensis (Ro1) and Globodera pallida (Pa2) eggs and juveniles

\begin{tabular}{|c|c|c|c|c|c|}
\hline \multirow[b]{2}{*}{ Species } & \multirow{2}{*}{$\begin{array}{c}\text { Application } \\
\text { rate } \\
{\left[1 \cdot \mathrm{ha}^{-1}\right]}\end{array}$} & \multicolumn{4}{|c|}{ Number } \\
\hline & & $\begin{array}{l}\text { cysts } \cdot 400 \mathrm{~g}^{-1} \\
\text { of soil }\end{array}$ & $\begin{array}{c}\text { eggs and } \\
\text { juveniles } \cdot \text { cyst }^{-1}\end{array}$ & $\begin{array}{c}\text { eggs and } \\
\text { juveniles } \cdot \mathrm{g}^{-1} \text { of soil }\end{array}$ & $r=P f / P i$ \\
\hline \multirow{9}{*}{$\begin{array}{l}\text { Globodera } \\
\text { rostochiensis }\end{array}$} & 0 & $217.8 a^{*}$ & $215.3 \mathrm{a}$ & $117.2 \mathrm{a}$ & $23.4 \mathrm{a}$ \\
\hline & 10 & $155.5 \mathrm{~b}$ & $171.0 \mathrm{~b}$ & $66.5 \mathrm{~b}$ & $13.3 \mathrm{~b}$ \\
\hline & $10+10$ & $153.8 \mathrm{~b}$ & $185.8 \mathrm{~b}$ & $71.4 \mathrm{~b}$ & $14.3 \mathrm{~b}$ \\
\hline & 20 & $139.0 \mathrm{bc}$ & $163.0 \mathrm{c}$ & $56.6 \mathrm{c}$ & $11.3 \mathrm{c}$ \\
\hline & $20+20$ & $124.0 \mathrm{c}$ & $164.8 \mathrm{c}$ & $51.1 \mathrm{c}$ & $10.2 \mathrm{c}$ \\
\hline & 40 & $104.0 \mathrm{~d}$ & $169.5 \mathrm{c}$ & $44.8 \mathrm{~cd}$ & $9.0 \mathrm{~cd}$ \\
\hline & $40+40$ & $101.8 \mathrm{~d}$ & $158.5 \mathrm{c}$ & $40.3 \mathrm{~d}$ & $8.1 \mathrm{~d}$ \\
\hline & 60 & $78.5 \mathrm{e}$ & $147.3 \mathrm{~d}$ & $28.9 \mathrm{e}$ & $5.8 \mathrm{e}$ \\
\hline & $60+60$ & $58.0 \mathrm{f}$ & $150.5 \mathrm{~d}$ & $21.8 \mathrm{f}$ & $4.4 \mathrm{f}$ \\
\hline \multirow{9}{*}{$\begin{array}{l}\text { Globodera } \\
\text { pallida }\end{array}$} & 0 & $244.5 \mathrm{a}$ & $222.3 \mathrm{a}$ & $135.9 \mathrm{a}$ & $30.2 \mathrm{a}$ \\
\hline & 10 & $179.5 \mathrm{~b}$ & $191.3 \mathrm{~b}$ & $85.7 \mathrm{~b}$ & $19.0 \mathrm{~b}$ \\
\hline & $10+10$ & $180.0 \mathrm{~b}$ & $198.0 \mathrm{~b}$ & $89.1 \mathrm{~b}$ & $19.8 \mathrm{~b}$ \\
\hline & 20 & $169.0 \mathrm{c}$ & $188.0 \mathrm{~b}$ & $79.4 \mathrm{c}$ & $17.7 \mathrm{c}$ \\
\hline & $20+20$ & $152.5 \mathrm{~d}$ & $155.3 \mathrm{c}$ & $59.2 \mathrm{~d}$ & $13.2 \mathrm{~d}$ \\
\hline & 40 & 150.0 de & $157.3 \mathrm{c}$ & $59.0 \mathrm{~d}$ & $13.1 \mathrm{~d}$ \\
\hline & $40+40$ & $138.5 \mathrm{e}$ & $159.0 \mathrm{c}$ & $55.1 \mathrm{~d}$ & $12.2 \mathrm{~d}$ \\
\hline & 60 & $135.8 \mathrm{e}$ & $130.0 \mathrm{~d}$ & $44.1 \mathrm{e}$ & $9.8 \mathrm{e}$ \\
\hline & $60+60$ & $99.5 \mathrm{f}$ & $138.0 \mathrm{~d}$ & $34.3 \mathrm{f}$ & $7.6 \mathrm{f}$ \\
\hline
\end{tabular}

*different letters within a column and species indicate significant differences $(\mathrm{p} \leq 0.05)$

$P f$ - final population density, $P i$ - initial population density

(Pseudococcus sp.), and aphids (Myzus persicae) (Arancon et al. 2007).

Our results, though, indicated that aqueous extracts of vermicompost were more effective than solid vermicompost in the suppression of potato-cyst nematodes (Tables 2, 3). Suppression was increased with the addition of urea to the aqueous extracts of vermicompost. The number of cysts $\cdot 400 \mathrm{~g}^{-1}$ of soil, the number of eggs and $\mathrm{J} 2 \mathrm{~s} \cdot \mathrm{g}^{-1}$ of soil, and thus the reproduction of both nematode species, decreased exponentially with an increase in the application dose and number of soil treatments. The double application (at potato sowing and one month later) significantly increased ( $\mathrm{p} \leq 0.05)$ suppression relative to the same doses applied only at sowing, mainly at the higher doses. The numbers of G. rostochiensis and G. pallida eggs and J2s per cyst did not differ significantly $(p \geq 0.05)$ between the single and double applications of some doses of both the vermicompost teas (with or without urea). Our results agree with those previously reported where vermicompost teas have suppressed plant par- 
Table 3. The effect of vermicompost tea with urea applied at various doses and times on the mean numbers (four replicates) of Globodera rostochiensis (Ro1) and Globodera pallida (Pa2) eggs and juveniles

\begin{tabular}{|c|c|c|c|c|c|}
\hline \multirow[b]{2}{*}{ Species } & \multirow{2}{*}{$\begin{array}{c}\text { Application } \\
\text { rate } \\
{\left[1 \cdot \mathrm{ha}^{-1}\right]}\end{array}$} & \multicolumn{4}{|c|}{ Number } \\
\hline & & $\begin{array}{l}\text { cysts } \cdot 400 \mathrm{~g}^{-1} \\
\text { of soil }\end{array}$ & $\begin{array}{c}\text { eggs and } \\
\text { juveniles } \cdot \text { cyst }^{-1}\end{array}$ & $\begin{array}{c}\text { eggs and } \\
\text { juveniles } \cdot \mathrm{g}^{-1} \text { of soil }\end{array}$ & $r=P f / P i$ \\
\hline \multirow{9}{*}{$\begin{array}{l}\text { Globodera } \\
\text { rostochiensis }\end{array}$} & 0 & $217.8 \mathrm{a}^{*}$ & $215.3 \mathrm{a}$ & $117.2 \mathrm{a}$ & $23.4 \mathrm{a}$ \\
\hline & 10 & $139.8 \mathrm{bc}$ & $188.3 \mathrm{~cd}$ & $65.8 \mathrm{~b}$ & $13.2 \mathrm{~b}$ \\
\hline & $10+10$ & $135.3 \mathrm{c}$ & $189.8 \mathrm{bc}$ & $64.1 \mathrm{~b}$ & $12.8 \mathrm{~b}$ \\
\hline & 20 & $136.0 \mathrm{c}$ & $170.0 \mathrm{cdef}$ & $57.8 \mathrm{bc}$ & $11.6 \mathrm{c}$ \\
\hline & $20+20$ & $121.8 \mathrm{c}$ & 179.0 cdef & $54.5 \mathrm{c}$ & $10.9 \mathrm{c}$ \\
\hline & 40 & $98.5 \mathrm{~d}$ & 181.3 cde & $44.6 \mathrm{~d}$ & $8.9 \mathrm{~d}$ \\
\hline & $40+40$ & 80.0 de & 164.5 def & $32.9 \mathrm{e}$ & $6.6 \mathrm{e}$ \\
\hline & 60 & $69.8 \mathrm{e}$ & $169.3 \mathrm{ef}$ & $29.5 \mathrm{e}$ & $5.9 \mathrm{e}$ \\
\hline & $60+60$ & $46.8 \mathrm{f}$ & $154.5 \mathrm{f}$ & $17.9 \mathrm{f}$ & $3.6 \mathrm{f}$ \\
\hline \multirow{9}{*}{$\begin{array}{l}\text { Globodera } \\
\text { pallida }\end{array}$} & 0 & $244.5 \mathrm{a}$ & $222.3 \mathrm{a}$ & $135.9 \mathrm{a}$ & $30.2 \mathrm{a}$ \\
\hline & 10 & $166.5 \mathrm{~b}$ & $190.0 \mathrm{~b}$ & $79.1 \mathrm{~b}$ & $17.6 \mathrm{~b}$ \\
\hline & $10+10$ & $149.3 \mathrm{c}$ & $194.5 \mathrm{~b}$ & $72.5 \mathrm{bc}$ & $16.1 \mathrm{~b}$ \\
\hline & 20 & $141.3 \mathrm{c}$ & $190.3 \mathrm{~b}$ & $67.2 \mathrm{c}$ & $14.9 \mathrm{c}$ \\
\hline & $20+20$ & $128.5 \mathrm{~d}$ & $183.3 \mathrm{bc}$ & $58.9 \mathrm{~cd}$ & $13.1 \mathrm{~d}$ \\
\hline & 40 & $119.8 \mathrm{e}$ & $175.5 \mathrm{c}$ & $52.6 \mathrm{~d}$ & $11.7 \mathrm{e}$ \\
\hline & $40+40$ & $84.3 \mathrm{f}$ & $182.4 \mathrm{bc}$ & $38.4 \mathrm{e}$ & $8.5 \mathrm{f}$ \\
\hline & 60 & $68.8 \mathrm{~g}$ & $158.5 \mathrm{~d}$ & $27.3 \mathrm{f}$ & $6.1 \mathrm{~g}$ \\
\hline & $60+60$ & $35.0 \mathrm{~h}$ & $157.8 \mathrm{~d}$ & $13.8 \mathrm{~g}$ & $3.1 \mathrm{~h}$ \\
\hline
\end{tabular}

*different letters within a column and species indicate significant differences $(\mathrm{p} \leq 0.05)$

$P f$ - final population density, $P i$ - initial population density

asitic nematodes, such as M. hapla (Edwards et al. 2011) and Pratylenchus sp. on tomatoes (Nath and Singh 2011), and arthropod pests, such as green peach aphids (Myzus persicae), citrus mealy bugs (Planococcus citri), spider mites (Tetranychus urticae), cucumber beetles (Acalymma vittatum), and tobacco hornworms (M. sexta) (Edwards et al. 2009a, b).

The mechanisms by which vermicomposts and their aqueous extracts suppress plant parasitic nematodes after application to soil, are speculative (Edwards et al. 2011). Larger predator-prey populations can also contribute to lower densities of plant parasitic nematodes in vermicompost-treated soils (Renčo et al. 2010). Vermicomposts can increase the numbers of predatory or omnivorous nematodes or arthropods such as mites that selectively prey on plant parasitic nematodes (Bilgrami 1996; Renčo et al. 2010). Vermicomposts can promote the growth of nematode-trapping fungi and fungi that attack nematode cysts and may thereby influence the populations of plant parasitic nematodes (Kerry 1998). Moreover, some rhizobacteria from vermicompost substrates can colonise roots and kill parasitic nematodes by producing harmful enzymes and toxins (Siddiqui and Mahmood 1998). Nematodes can also be killed by toxic substances such as hydrogen sulfide, ammonia, and nitrites released during vermicompost degradation in the soil (Rodriguez-Kábana 1986). A higher availability of nitrogen enhances the nematicidal activity of manures against plant parasitic nematodes (Mian and Rodriguez-Kábana 1982). So, materials with lower $\mathrm{C}: \mathrm{N}$ ratios are more nematicidal than those with higher ratios (Kirmani et al. 1975; Ismail et al.
2006; Renčo et al. 2011). Similarly, the suppressive effect of organic amendments against nematodes has often been attributed to the toxicity of ammonia (Conn and Lazarovits 1999; Oka and Yermiyahu 2002; Renčo et al. 2011).

The treatments with vermicompost and vermicompost tea also substantially affected plant growth (Figs. $1,2)$. Stem fresh weight and height were significantly higher $(\mathrm{p} \leq 0.05)$ in the vermicompost, and vermicompost-tea treatments (with and without urea) relative to the controls. The addition of urea to the aqueous extract significantly improved plant growth, compared to when no urea and only the solid vermicompost were used. Our data are in accordance with those from previous studies where a vermicompost addition increased plant growth in radishes (Buckerfield et al. 1999), tomatoes (Subler et al. 1998) or marigolds (Atiyeh et al. 2000). Vermicomposts have been reported to increase microbial activity in soils. The production of plant growth regulators such as gibberellins, cytokinins, auxins, and humates by microorganisms may promote plant growth, independent of the nutrient supply (Tomati et al. 1990). The use of vermicompost aqueous extracts to improve plant growth and yields, however, has received little attention. The chemistry and microbiology of extracts are complex. But soluble mineral plant nutrients, plant growth hormones and regulators, and microorganisms and their enzymes, likely have favourable effects on plant growth and yields (Edwards et al. 2011).

In conclusion, cyst-forming nematodes belong to a specific group of plant parasites and invade plant roots as infective J2s that hatch from eggs retained in protec- 


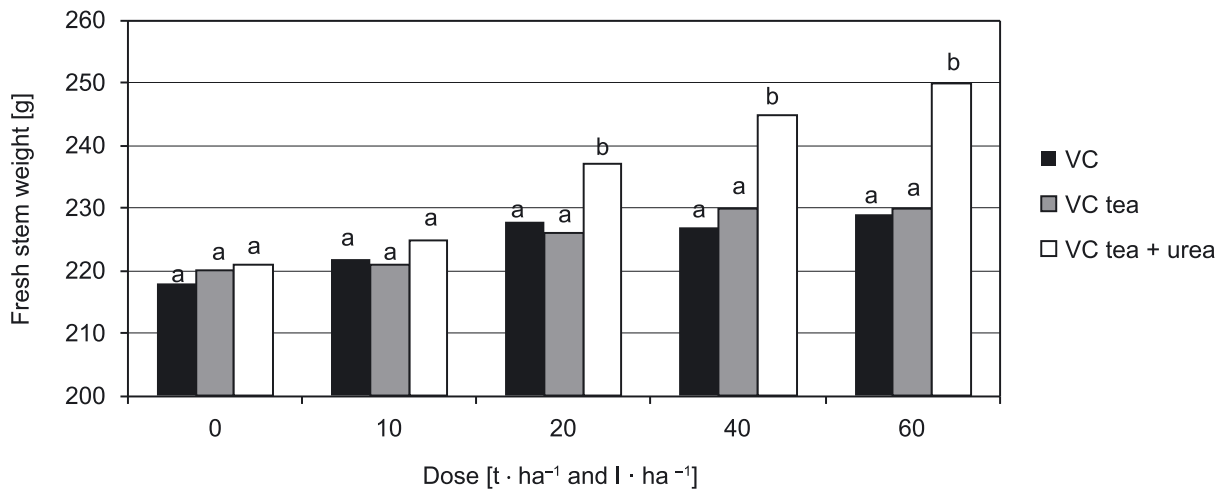

Fig. 1. The effect of vermicompost (VC), vermicompost tea and urea application at different doses on fresh stem weight of potato plants. Data flanked by the same letters are not statistically different according to least significant difference test $(\mathrm{p} \leq 0.05)$

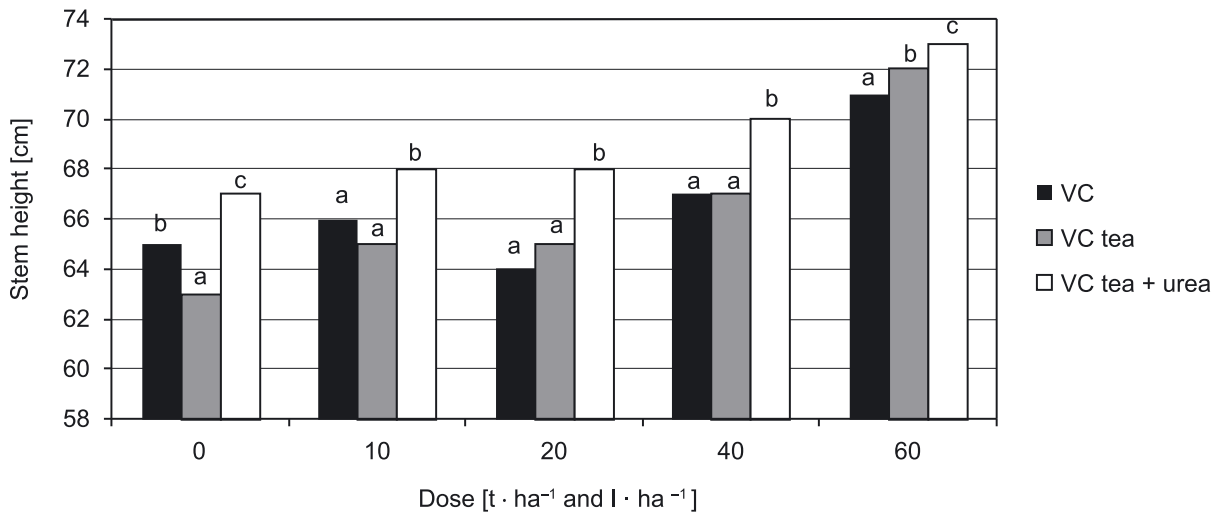

Fig. 2. The effect of vermicompost (VC), vermicompost tea and urea application at different doses on potato stem height. Data flanked by the same letters are not statistically different according to least significant difference test $(\mathrm{p} \leq 0.05)$

tive cysts (dead females of cyst nematodes) throughout plant growth. Treatment with solid vermicompost is only possible prior to potato planting. Liquid solutions such as vermicompost tea, though, can be applied throughout the crop season to suppress nematodes that hatch from cysts later in the season. The application of vermicompost tea in aqueous formulations, considerably decreases the amount of materials needed. Thus, there is a decreased cost of nematode management when using vermicompost tea in aqueous formulations.

\section{Acknowledgements}

The authors acknowledge the support of the scientific grant agency VEGA, projects no. 2/0079/13 and 1/0591/13.

\section{References}

Akhtar M. 1997. Current options in integrated management of plant-parasitic nematodes. Integrated Pest Management Reviews 2: 187-197.

Arancon N.Q., Edwards C.A., Bierman P., Metzger J.D., Lucht C. 2005. Effects of vermicomposts produced from cattle manure, food waste and paper waste on the growth and yields of peppers in the field. Pedobiologia 49 (4): 297-306.

Arancon N.Q., Edwards C.A., Lee S.S., Yardim E. 2002. Management of plant parasitic nematode populations by use of vermicomposts. p. 705-710. In: Proceedings of Brighton
Crop Protection Conference - Pest and Disease, Brighton, UK, 18-21 November, 2002.

Arancon N.Q., Edwards C.A., Oliver T.J., Byrne R.J. 2007. Suppression of two-spotted spider mite (Tetranychus urticae) mealy bug (Pseudococcus sp.) and aphid (Myzus persicae) populations and damage by vermicomposts. Crop Protection 26 (1): 26-39.

Atiyeh R.M., Subler S., Edwards C.A., Bachman G., Metzger J.D., Shuster W. 2000. Effects of vermicomposts and composts on plant growth in horticultural container media and soil. Pedobiologia 44 (5): 579-590.

Avato P., D'Addabbo T., Leonetti P., Argentieri M.P. 2013. Nematicidal potential of Brassicaceae. Phytochemical Review 12 (4): 791-802.

Bilgrami A.L. 1996. Evaluation of the predation abilities of the mite Hypoaspis calcuttaensis, predaceous on plant and soil nematodes. Fundamental \& Applied Nematology 20: 96-98.

Brown E.B. 1969. Assessment of the damage caused to potatoes by potato cyst eelworm Heterodera rostochiensis Woll. Annals of Applied Biology 63 (3): 493-502.

Buckerfield J.C., Flavel T., Lee K.E., Webster K.A. 1999. Vermicomposts in solid and liquid form as plant growth promoter. Pedobiologia 43 (6): 753-759.

Conn K.L., Lazarovits G. 1999. Impact of animal manures on Verticillium wilt, potato scab and soil microbial community. Canadian Journal of Plant Pathology 21 (1): 81-92.

Edwards C., Arancon N.Q., Vasko-Bennett M., Askar A., Keeney G., Little B. 2009a. Suppression of green peach aphid (Myzus persicae) (Sulz.), citrus mealy bug (Planococcus citri) 
(Risso) and two spotted mite (Tetranychus urticae) (Koch.) attacks on tomatoes and cucumber by aqueous extracts from vermicomposts. Crop Protection 29 (1): 80-93.

Edwards C., Arancon N.Q., Vasko-Bennett M., Askar A., Keeney G. 2009b. Effect of aqueous extracts from vermicomposts on attacks by cucumber beetles (Acalymna vittatum) (Fabr.) on cucumbers and tobacco hornworms (Manduca sexta) on tomatoes. Pedobiologia 53 (2): 141-148.

Edwards C., Arancon N.Q., Sherman R. 2011. Vermiculture Technology. CRC Press, USA, 623 pp.

EPPO 2014. A1 and A2 Lists of Pests Recommended for Regulation as Quarantine Pests. European and Mediterranean Plant Protection Organization, Paris, France, 16 pp.

Evans K., Haydock P.P.J. 1990. A review of tolerance by potato plants of cyst nematode attack, with consideration of what factors may confer tolerance and methods of assaying and improving it in crops. Annals of Applied Biology 117 (3): 703-740.

Greco N. 1988. Potato Cyst Nematodes: Globodera rostochiensis and G. pallida. Nematology Circular No. 149. Florida Department of Agriculture and Consuner Services, Division of Plant Industry, Gainesville, FL, USA, 4 pp.

Haydock P.P.J., Woods S.R., Grove I.G., Hare M.C. 2013. Chemical control of nematodes. p. 259-279. In: "Plant Nematology" (R.N. Perry, M. Moens, eds.). 2nd ed. CABI, Wallingord, UK, 568 pp.

Ismail A.E., Rawia A.E, El-Nagdi W.M.A. 2006. Effect of different composts, biofertilizers and olive pomace as soil amendments on Rotylenchulus reniformis, growth and chemical analysis of jasmine Egypt. Journal of Applied Science Research 2 (11): 909-916.

Karajeh M.R. 2008. Interaction of root-knot nematode (Meloidogyne javanica) and tomato as affected by hydrogen peroxide. Journal of Plant Protection Research 48 (2): 181-187.

Kerry B. 1988. Fungal parasites of cyst nematodes. p. 293-306. In: "Biological Interactions in Soil" (C.A. Edwards, B.R. Stinner, D. Stinner, S. Rabatin, eds.). Elsevier, 380 pp.

Kirmani M.R., Alam M.M., Khan A.M., Saxena S.K. 1975. Effect of different carbon: nitrogen ratios on the population of nematodes and fungi and plant growth of cabbage. Indian Journal of Mycology and Plant Pathology 5: 22-30.

Mian I.H., Rodríguez-Kábana R. 1982. Soil amendments with oil cakes and chicken litter for control of Meloidogyne arenaria. Nematropica 12 (2): 205-220.

Nath G., Singh K. 2011. Combination of vermicomposts and biopesticides against nematode (Pratylenchus sp.) and their effect on growth and yield of tomato (Lycopersicon esculentum). IIOAB Journal 2: 27-35

Oijen M.V., De Ruijter F.J., Van Haren R.J.F. 1995. Analyses of the effects of potato cyst nematodes (Globodera pallida) on growth, physiology and yield of potato cultivars in field plots at three levels of soil compaction. Annals of Applied Biology 127 (3) 499-520.
Oka Y., Yermiyahu U. 2002. Suppressive effects of composts against the root-knot nematode Meloidogyne javanica on tomato. Nematology 4 (8): 891-898.

Pandey R. 2005. Management of Meloigodyne incognita in Artemisia pallens with bio-organics. Phytoparasitica 33 (3): 304-308.

Renčo M., Sasanelli N., D’Addabbo T., Papajová I. 2010. Soil nematode community changes associated with composts amendment. Nematology 12 (5): 681-692.

Renčo M. 2013. Organic amendments of soil as useful tools of plant parasitic nematodes control: review. Helminthologia 50 (1): 3-14.

Renčo M., Sasanelli N., Kováčik P. 2011. The effect of soil compost treatments on potato cyst nematodes Globodera rostochiensis and Globodera pallida. Helminthologia 48 (3): 184-194.

Renčo M., Sasanelli N., Maistrello L. 2014. Plants as natural sources of nematicides. p. 115-141. In: “Nematodes: Comparative Genomics, Disease Management and Ecological Importance. Chapter: Plants as Natural Sources of Nematicides" (Lee M. Davis, ed.). NOVA Science publisher, New York, 120 pp.

Rodriguez-Kábana R. 1986. Organic and inorganic amendments to soil as nematode suppressant. Journal of Nematology 18 (2): 129-135.

Sabová M., Valocká B. 1980. Parasitic nematodes of cereals in Slovak Republic. Agricultural 26: 278-258.

Sasanelli N., Takacs A.A., D’Addabbo T., Biro I., Malov X. 2009. Influence of arbuscular mycorrhizal fungi on the nematicidal properties of leaf extracts of Thymus vulgaris L. Helminthologia 46 (4): 230-240.

Seenivasan N., Poornima K. 2010. Bio-management of root-knot nematode, Meloidogyne incognita (Kofoid and White) Chitwood in jasmine (Jasminum sambac L.). Pest Management in Horticultural Ecosystem 16 (1): 34-40.

Sharma S.B. 1998. The Cyst Nematodes. Kluwer Academic Publishers, Dordrecht, The Netherlands, $452 \mathrm{pp}$.

Subler S., Edwards C.A., Metzger J. 1998. Comparing vermicomposts and composts. BioCycle 39: 63-66.

Tomati U., Galli E., Grappelli A., Dihena G. 1990. Effect of earthworm casts on protein synthesis in radish and lettuce seedlings. Biology and Fertility of Soils 9: 288-289.

Vasyukova N.I., Zinovieva S.V., Udalova Z.V., Pridorova S.M., Ozeretskovskaya O.L. 2006. Immunomodulating effect of elicitors and suppressors upon infection of potato with Globodera rostochiensis (Wollenweber, 1923) Beherens. Doklady Biological Sciences 411: 449-451.

Vibha M. 2010. Effect of fungal metabolites and amendments on mycelial growth of Rhizoctonia solani. Journal of Plant Protection Research 50 (1): 93-97.

Yardim E.N., Arancon N.Q., Edwards C.A., Oliver T.J., Byrne R.J. 2006. Suppression by vermicomposts of tomato hornworm (Manduca quinquemaculata) and cucumber beetle (Acalymma vittatum) populations and damage. Pedobiologia 50 (1): 23-29. 